\title{
Komunikasi Antarpribadi antara Orang Tua dan Anak Usia Remaja dalam Pembentukan Kepercayaan Diri Anak
}

\author{
Prima Frieda, H.H Daniel Tamburian \\ Prima.915160025@stu.untar.ac.id,danielt@fikom.untar.ac.id
}

Fakultas Ilmu Komunikasi Universitas Tarumanagara

\begin{abstract}
Communication between parents and children is one of the most important factors for a child's confidence. However, according to several surveys conducted, it shows that there are still many parents who do not really care about how to raise their children. Many parents only focus on the physical growth and education of the child, without paying attention to the mental development of the child's self-confidence. This study aims to learn how interpersonal communication between parents and teenagers in the formation of child's self-confidence. Interpersonal communication and self-confidence theory are the basis of this research. This research was conducted using qualitative descriptive methods. Data collection methods used are interviews, observation, and through secondary data. The results of the study indicate that interpersonal communication activities undertaken by parents and teenagers are crucial to the formation of child's self confidence. Parents who use the right communication style when communicating with children will influence their child to be more open and this openness that builds confidence in a child's personality.
\end{abstract}

Keywords: interpersonal communication, parents, teenagers, self confidence.

\begin{abstract}
Abstrak
Komunikasi antara orang tua dan anak merupakan salah satu faktor terpenting dalam membentuk kepercayaan diri anak. Namun, menurut beberapa survey yang dilakukan, menunjukkan bahwa masih banyak orang tua yang tidak benar-benar peduli terhadap pola didik yang mereka berikan terhadap anak-anaknya. Banyak orang tua yang hanya fokus pada pertumbuhan fisik dan pendidikan anak saja, tanpa memperhatikan perkembangan mental khususnya kepercayaan diri anak. Penelitian ini bertujuan untuk mengetahui peranan komunikasi antarpribadi orang tua dengan anak usia remaja dalam pembentukan kepercayaan diri anak. Teori komunikasi antarpribadi dan kepercayaan diri menjadi dasar dari penelitian ini. Penelitian ini dilakukan menggunakan pendekatan kualitatif dengan metode deskriptif. Metode pengumpulan data yang digunakan yaitu dengan melakukan wawancara, observasi, dan melalui data-data sekunder. Hasil dari penelitian menunjukan bahwa aktivitas komunikasi antarpribadi yang dilakukan orang tua dan anak usia remaja sangat menentukan pembentukan kepercayaan diri anak. Orang tua yang menggunakan gaya komunikasi yang tepat saat berkomunikasi dengan anak membuat anak lebih terbuka dan kemudian keterbukaan ini yang membangun kepercayaan diri dalam pribadi anak.
\end{abstract}

Kata Kunci: anak remaja, kepercayaan diri, komunikasi antarpribadi, orang tua.

\section{Pendahuluan}

Sebagai makhluk sosial manusia selalu melakukan proses komunikasi satu dengan yang lain secara sengaja maupun tidak disengaja yang bertujuan untuk memenuhi kebutuhan fisik ataupun jasmani (Setiawan \& Azeharie, 2017). Komunikasi 
merupakan faktor paling penting dalam suatu hubungan. Dalam komunikasi, terjadi proses penyampaian makna dari komunikator ke komunikan (Littlejohn dan Foss, 2009). Komunikasi yang akan dibahas lebih dalam pada penelitian ini adalah komunikasi antarpribadi. Menurut Joseph A. DeVito (2016) komunikasi antarpribadi merupakan suatu proses hubungan timbal balik secara lisan maupun tulisan yang melibatkan lebih dari satu orang. Komunikasi antarpribadi yang paling sederhana dapat kita lihat dalam hubungan keluarga. Namun, sayangnya banyak orang tua yang tidak menyadari bahwa mereka memiliki peranan yang sangat vital dalam tumbuh kembang anak. Banyak orang tua yang tidak memiliki cukup pengetahuan untuk mendidik anak (Gunarsa, 2008).

Bahkan hasil survey KPAI pada 2015 tentang "Pemenuhan Hak Pengasuhan Anak" yang melibatkan 800 responden keluarga, hanya 27,9\% ayah dan $36,6 \%$ ibu yang mencoba memperoleh informasi mengenai cara mendidik anak sebelum menikah. Artinya, persiapan dari sisi pengetahuan orang tua masih sangat jauh dari ideal. Dalam survei tersebut juga ditemukan sebanyak $66,4 \%$ ayah dan $71 \%$ ibu mengikuti pola didik ketika mereka kecil. Padahal pada kenyataannya, kondisi dan lingkungan anak masa kini berbeda dengan kondisi dan lingkungan anak masa lalu.

Sangat penting bagi anak untuk memiliki tumbuh kembang yang baik dari berbagai aspek, terutama dalam hal kepercayaan diri. Rasa percaya terhadap diri sendiri memampukan anak dalam menghadapi tantangan yang dalam kehidupan sehari-hari, mengembangkan kemampuan yang dimiliki dan menyesuaikan perilaku yang benar. Kepercayaan diri dapat terbentuk melalui komunikasi yang baik terhadap anaknya, baik melalui komunikasi verbal maupun non verbal. Misalnya dengan menanamkan kata-kata motivasi kepada anak, jika anak salah diberitahu dengan baik dan tetap memberikan dukungan kepada anak, membangun anak dengan gambaran diri yang positif, dan lain-lain. Namun, masih banyak orang tua yang tidak sadar akan pengaruh dari setiap kata-kata yang mereka keluarkan terhadap anak, banyak orang tua yang kemudian melunturkan semangat dan harapan anak melalui kata-katanya (Harapan dan Ahmad, 2014).

Anak usia remaja mulai memasuki masa peralihan dari usia anak-anak ke dewasa. Karakter dan sikap dibentuk pada masa-masa ini untuk persiapan anak di usia dewasa. Di usia remaja ini, anak sedang mencari jati dirinya yang sesungguhnya. Oleh karena itu, anak sedang membutuhkan kasih sayang dan dukungan dari orang-orang terdekatnya, terutama keluarga. Ditambah dengan kemajuan teknologi dan media sosial mempermudah anak untuk melihat berbagai gaya hidup yang mewah dari media sosial. Banyak remaja yang mengukur nilai diri mereka melalui seberapa mereka aktif dan terkenal di media sosial. Kehadiran keluarga dan teman-teman dekat sangat diperlukan pada masa-masa ini (Gunarsa, 2008).

Berdasarkan latar belakang di atas, dan mengingat pentingnya komunikasi antara orang tua dan anak khususnya dalam pembentukan kepercayaan diri di usia remaja, membuat penulis tertarik untuk membuat penelitian dengan topik "Komunikasi Antarpribadi antara Orang Tua dan Anak Usia Remaja dalam Pembentukan Kepercayaan Diri Anak". Dengan tujuan agar melalui penelitian ini, dapat menambah ilmu dan pengetahuan mengenai komunikasi antarpribadi antara orang tua dan anak usia remaja dalam pembentukan kepercayaan diri anak.

Penelitian ini menggunakan teori komunikasi, komunikasi antar pribadi yang meliputi komunikasi verbal dan non-verbal serta jendela johari, dan teori kepercayaan diri serta self-esteem sebagai dasar dari penelitian ini. 
Prima Frieda, H.H Daniel Tamburian: Komunikasi Antarpribadi antara Orang Tua dan Anak Usia Remaja dalam Pembentukan Kepercayaan Diri Anak

\section{Metode Penelitian}

Pada penelitian ini, penulis menggunakan metode penelitian kualitatif secara deskriptif. Flick (2002) mendefinisikan penelitian kualitatif merupakan hubungan antara fenomena sosial yang terjadi di masyarakat dengan teori dan kebenaran yang ada. Alasan penulis memilih pendekatan kualitatif adalah penulis ingin penelitian ini memiliki wawasan yang luas dan mendalam tentang aspek yang diteliti.

Penulis memilih metode kualitatif yang bersifat deskriptif untuk penelitian ini. Penelitian deskriptif menjelaskan peristiwa sosial apa yang sedang muncul di masyarakat (Ruslan, 2013). Alasan penulis menggunakan metode deskriptif, karena penulis ingin mengkaji penelitian tentang komunikasi antar pribadi antara orang tua dan anak usia remaja dalam pembentukan kepercayaan diri secara lebih rinci dan mendalam.

Menurut Rosady Ruslan dalam buku Manajemen Public Relations \& Media Komunikasi, subjek adalah sumber yang akan memberikan informasi terkait dengan topik penelitian serta memiliki keterkaitan dengan topik penelitian (Ruslan, 2010). Adapun daftar nama dari subyek yang akan penulis teliti adalah: Randy, beserta orang tuanya Ibu Lim, dan orang ketiga Bella. Informan 2: Thessalonika, beserta orang tuanya Ibu Evi, dan orang ketiga Olivia. Informan 3: Bella, beserta orang tuanya Ibu Asi, dan orang ketiga Soveta. Informan 4: Sella, beserta orangtuanya Bapak Hendra, beserta orang ketiga Chindy.

Objek merupakan gambaran umum dari apa yang akan diteliti (Bungin, 2007). Objek dalam penelitian ini adalah komunikasi antar pribadi antara orang tua dan anak usia remaja dalam pembentukan mental anak.

Terdapat 2 metode pengumpulan data, yakni primer dan sekunder. Menurut Ruslan (2013), data primer adalah metode pengumpulan data dengan meneliti secara langsung ke lapangan. Pada penelitian ini, peneliti menggunakan 2 metode pengumpulan data primer, yakni: wawancara dan observasi. Menurut Bungin (2010), data sekunder merupakan data yang sudah ada dan dapat digunakan untuk mendukung data primer. Data sekunder pada penelitian ini melalui teknik pengumpulan data khusus.

Menurut Spradley (1980), analisis data kualitatif adalah proses pemecahan suatu data agar dapat dipaparkan dan ditarik kesimpulan (Gunawan, 2014: 210). Terdapat tiga tahapan dalam menganalisis data penelitian kualitatif, yaitu : reduksi data (data reduction), paparan data (data display), penarikan kesimpulan dan verifikasi (conclusion drawing/verifying).

Data yang berhasil dikumpulkan merupakan bahan penelitian yang sangat penting. Triangulasi data dapat dijadikan sebagai alat untuk menganalisis data. Menurut Mantja (2007), triangulasi dapat digunakan untuk proses untuk mendukung kebenaran suatu data agar dapat dipercaya (Gunawan, 2014). Untuk memastikan keabsahan data, penulis akan menggunakan triangulasi data yang meliputi: triangulasi sumber, triangulasi metode, triangulasi peneliti, dan triangulasi teori.

\section{Hasil Temuan dan Diskusi}

\section{Kesadaran Anak dan Orang Tua akan Pentingnya Komunikasi}

Komunikasi merupakan hal yang sangat penting dalam suatu hubungan. Berdasarkan wawancara yang telah dilakukan oleh penulis, semua informan yang telah diwawancarai setuju bahwa komunikasi itu hal yang penting. Antara orang tua dan 
anak dari setiap informan yang telah diwawancara, terdapat persamaan pada gaya komunikasi. Dimana rata-rata orang tua berkomunikasi dengan anaknya menerapkan gaya komunikasi lingkaran dimana setiap partisipan (anak) dapat dengan bebas bertukar pendapat dan mengeluarkan opininya. Namun, disaat-saat tertentu yang membutuhkan ketegasan, orang tua dapat menggunakan pola roda juga, dimana ada satu pemimpin sebagai pusat dari komunikasi yang dilakukan. Namun, ada juga seorang informan yang lebih memposisikan dirinya sebagai orang tua dan pengambil keputusan. Disini informan mengaku kurang menerima pendapat dari si anak dan cenderung enggan berdiskusi dalam mengambil sebuah keputusan.

"Iya, saya biasa kalo udah A yah A. B yah B. Tapi kalo saya udah capek yah suka-suka dia aja deh.” (Orang tua, informan 4)

Orang tua pada informan 1,2, dan 3 mengaku bahwa sesibuk-sibuknya mereka, akan tetap menyempatkan waktu untuk berkomunikasi dengan anak mereka. Hal ini sudah menunjukkan keterbukaan sesuai dengan salah satu karakteristik komunikasi antarpribadi, dimana anak mau terbuka dan menceritakan dirinya kepada orang tuanya (DeVito, 2010). Berbanding terbalik dengan informan 4 yang mengaku jarang melakukan komunikasi dengan anaknya karena kesibukan.

\section{Komunikasi Antarpribadi antara Orang Tua dan Anak Usia Remaja}

a. Komunikasi Verbal dan Non-verbal

Komunikasi antarpribadi merupakan suatu hubungan timbal balik secara lisan dan tulisan yang melibatkan lebih dari satu orang. Berdasarkan wawancara yang telah dilakukan, informan yang sudah diwawancara mengakui bahwa komunikasi dengan kata-kata (verbal) tidaklah cukup, namun harus didukung oleh komunikasi non-verbal yang dapat berupa ekspresi wajah, gerakan tubuh, intonasi suara, dan lain-lain.

"Kalo body language emang kadang kalo kita jelasin sesuatu ada body languagenya. Agar orang tua lebih memahami. Misal, untuk ngerjain apa atau gimana ada gerakan yang kita lakuin ke orang tua. Biar orang tua lebih ngerti gitu. Kalo soal intonasi, saya biasa aja gak terlalu tinggi atau keras. " (Anak, informan 1)

Informan setuju bahwa komunikasi non-verbal membantu mereka dalam menafsirkan makna komunikasi menjadi lebih baik dan terhindar dari kesalahpahaman (Budyatna dan Ganiem, 2011). Komunikasi verbal penting untuk membantu kita menyampaikan makna dari apa yang kita katakan. Menggunakan komunikasi nonverbal pun harus berhati-hati, karena jika unsur komunikasi non-verbal yang digunakan tidak sesuai dengan makna yang ingin disampaikan, sangat rentan menimbulkan kesalahpahaman atau missed communication. Anak dapat menangkap perasaan dan maksud dari orang tua hanya dari sentuhan yang diberikan. Seperti wawancara di atas, tanpa ibunya mengatakan sayang kepada anaknya, anak dapat langsung mengetahui bahwa ibunya sayang kepadanya hanya melalui pelukan atau sentuhan fisik yang diberikan.

b. Keterbukaan Menurut Jendela Johari (Johari Window)

Dalam jendela johari terdapat kuadran-kuadran yang menggambarkan seberapa besar keterbukaan seseorang terhadap orang lain dan juga seberapa besar orang lain mengenalnya. Jika dikaitkan dengan penjelasan tersebut, dapat diketahui bahwa setiap orang pasti memiliki aspek dimana mereka dapat membuka dirinya pada orang lain, terdapat juga aspek dimana mereka menyembunyikan diri atau perasaan mereka terhadap orang lain, terdapat juga aspek dimana seseorang tidak menyadari apa yang 
ternyata ada pada dirinya namun hal itu dapat dilihat oleh orang lain, dan aspek dimana seseorang dan orang lain tidak mengetahui sama sekali apa yang ternyata ada dalam diri orang tersebut. Melalui wawancara yang sudah dilakukan oleh peneliti, dapat dilihat seberapa besar anak telah membuka dirinya pada orang tua dan seberapa besar orang tua mengenal anaknya.

"Untuk saat ini sih lebih kaya seadanya aja, tapi, yah sometimes sih ada diskusi lah kalo yang nyangkut penting-penting dan butuh keputusan orang tua. Tapi kalo hal-hal pribadi gak sering ya soalnya nyokap aku cuek." (Anak, informan 1)

Informan 1 mengaku telah sering melakukan komunikasi dengan ibunya, namun, untuk hal-hal yang sekiranya lebih penting dan menyangkut keperluannya saja. Dan, menurut observasi yang dilakukan, peneliti dapat menilai ibu dari informan 1 lebih bersikap cuek pada anaknya. Dari sini penulis dapat melihat bahwa hubungan baik saja belum cukup untuk membuat antar individu memiliki keterbukaan.

Berbeda dengan informan 1 yang kurang terbuka mengenai hal pribadi dengan orang tuanya, informan 2 dan 3 mengaku sangat sering bercerita mengenai apa yang mereka alami dan hadapi pada orang tuanya. Orang tua informan 2 dan 3 pun mengaku bahwa mereka sangat mengenal watak dan karakter dari anak-anaknya secara mendalam. Orang tua informan 2 dan 3 juga terlihat sangat mengikuti perkembangan zaman agar tetap relevan dan nyambung dengan anak-anak mereka. Dari sini dapat dilihat bahwa informan 2 dan 3 telah memiliki karakteristik komunikasi antarpribadi yang baik, dimana mereka ada keterbukaan, empati sikap mendukung, sikap positif, dan kesetaraan dalam hubungan mereka (DeVito, 2010: 285).

"Kalau untuk sekedar curhat sharing sih sangat chill, karena mami tuh gaul jadi lebih ngerti yang lagi hits. Jadi kalo mau bahas apa lebih masuk.” (Orang ketiga, narasumber 2)

Temuan lainnya terdapat pada informan 4. Berdasarkan observasi peneliti terhadap informan 4, peneliti melihat bahwa orang tua informan 4 sibuk sendiri dengan urusannya dan jarang mengajak anaknya berkomunikasi. Dari wawancara yang telah dilakukan, dapat dilihat berbagai perbandingan mengenai tingkat keterbukaan anak terhadap orang tuanya. Jika informan 2 dan 3 mengaku telah terbuka terutama hal-hal penting terhadap orang tuanya, informan 1 dan 4 mengaku tidak mau bercerita mengenai hal penting dan personal pada orang tuanya. Dari sini dapat dilihat bahwa tidak ada keterbukaan dalam hubungan informan 1 dan 4 dengan orang tuanya.

\section{Kepercayaan Diri Anak Remaja}

Tingkat Kepercayaan Diri Anak dan Peran Orang Tua di Dalamnya

Kepercayaan diri merupakan hal yang sangat penting dan harus dimiliki oleh setiap orang. Banyak hal yang mempengaruhi pembentukan kepercayaan diri seseorang dan salah satunya adalah komunikasi dengan orang tua. Informan 4 mengaku belum memiliki kepercayaan diri yang cukup baik. Begitu pula dengan informan 1 yang juga mengaku belum memiliki kepercayaan diri yang maksimal.

Sedangkan informan 2, dan 3 mengaku telah memiliki kepercayaan diri yang cukup baik. Berdasarkan wawancara dengan orang tua dan orang ketiga dari informan 2, dan 3, mereka juga mengaku bahwa anak-anak ini sudah memiliki kepercayaan diri yang cukup baik dan dapat membangun relasi yang baik di masyarakat. Kepercayaan diri yang berhasil dimiliki oleh informan 2 dan 3 tidak lepas dari peran orang tua mereka. Orang tua dari informan 2 dan 3 mengaku untuk selalu memberikan dukungan untuk anak-anak mereka dan selalu mengarahkan anak-anak mereka sesuai dengan 
bakat yang sekiranya dimiliki oleh anak-anak tersebut. Jika anak-anak ini melakukan kesalahan, orang tua informan 2 dan 3 mengaku tidak pernah memarahi mereka dan terus memberikan dukungan serta mengingatkan tidak apa-apa mereka membuat kesalahan, karena dari kesalahan itu mereka dapat belajar.

"Mensupport mereka. Mereka hobinya apa, tante arahin. Tante dukung, pasti bisa. Tante nasehatin, kenapa bisa? Kenapa orang bisa, kalian sama-sama makan nasi, kenapa mereka bisa ranking? Makanannya sama, minumannya sama, buahnya sama, berarti kamu juga bisa." (Orang tua, informan 2)

Berdasarkan observasi yang telah peneliti lakukan terhadap informan 2 dan 3 , peneliti melihat bahwa orang tua informan 2 dan 3 merupakan orang tua yang bisa diajak berdiskusi serta selalu memberikan dukungan bagi anak-anaknya. Peneliti menilai bahwa orang tua ini tidak fokus pada hasil yang dicapai oleh anak-anaknya saja, namun fokus pada proses pencapaian dan setiap pelajaran yang didapat. Mereka selalu memberikan yang terbaik untuk anak-anaknya dapat mengembangkan potensi diri yang dimiliki. Berbeda dengan orang tua informan 1 dan 4, mereka sama-sama menyadari akan pentingnya kepercayaan diri pada anak, namun, tidak benar-benar membangun nilai tersebut dalam diri anak-anaknya. Mereka lebih bersikap acuh tak acuh terhadap bakat dan minat anaknya. Dari sini juga dapat dilihat bahwa orang tua yang memiliki karakteristik komunikasi antarpribadi yang baik dengan anak, seperti sikap empati, sikap mendukung, sikap positif, dan kesetaraan dapat mendorong anak memiliki keterbukaan dengan orang tuanya (DeVito, 2010).

\section{Self-esteem}

Self-esteem merupakan cara pandang seseorang mengenai dirinya sendiri (Minchinton, 2005). Jika seseorang berhasil memiliki cara pandang yang baik dan positif mengenai dirinya, maka ia akan cenderung memiliki kepercayaan diri yang baik. Sebaliknya, jika seseorang tidak memiliki kepercayaan diri yang baik maka kepercayaan dirinya pun akan rendah. Contoh, anak yang percaya bahwa dirinya berharga dan mampu melakukan hal-hal hebat, maka ia akan memiliki kepercayaan diri untuk melakukan sesuatu dan masuk ke dalam lingkungan masyarakat. Namun, dari hasil wawancara yang telah dilakukan, hanya informan 1 yang mengaku telah memiliki cara pandang yang positif mengenai dirinya.

"Pastinya saya memandang diri saya berharga. Karena, orang tua udah ngedidik sampai saat ini kan. Jadi, saya mau memandang diri saya lebih berharga dan berguna buat temen-temen saya. Gituuu." (Anak, informan 1)

Sedangkan informan 2, 3, dan 4 mengaku masih belum memiliki kepercayaan diri yang cukup baik mengenai diri mereka. Mereka masih suka ragu akan setiap potensi yang mereka miliki dan juga mengaku bahwa mereka sering kali labil terhadap perasaan dan keputusan.

Walaupun informan 2 dan 3 sebelumnya telah mengaku memiliki kepercayaan diri yang cukup baik, namun, ternyata hal itu tidak menjamin mereka untuk memiliki cara pandang yang benar akan diri mereka.

\section{Keseimbangan antara Gaya Komunikasi yang Digunakan dalam Pembentukan Kepercayaan Diri Anak}

Melalui wawancara dan observasi yang telah dilakukan, dapat dilihat bagaimana perbedaan antara komunikasi orang tua dan anak yang terjalin dengan baik dan intens dengan komunikasi antara orang tua dan anak yang kurang terjalin dengan baik dalam pembentukan kepercayaan diri anak. Orang tua dan anak yang memiliki 
komunikasi yang baik cenderung lebih terbuka dengan orang tua dan memiliki kepercayaan diri. Namun, belum banyak orang tua yang menyadari hal ini. Masih banyak orang tua yang bersikap terlalu cuek dan tidak peduli terhadap perkembangan anak mereka. Jika hal ini terus dibiarkan, misal orang dari informan ke 4 yang mengaku kurang memiliki komunikasi yang baik dengan anaknya serta bersikap cuek dan tidak dapat berdiskusi, maka pembentukan kepercayaan diri anak tidak akan maksimal. Anak akan melewati masa-masa emas dalam proses pembentukan kepercayaan diri. Sedangkan, kepercayaan diri sangat penting untuk bekal anak di masa depan. Seperti saat mereka memasuki masa-masa perguruan tinggi, mereka harus memasuki lingkungan baru dan memulai sosialisasi yang baru. Lalu, saat memasuki dunia kerja mereka juga dituntut untuk dapat beradaptasi dengan lingkungan kerjanya. Disinilah peran kepercayaan diri sangat diperlukan dan menentukan keberhasilan mereka dalam bersosialisasi dan beradaptasi (Minchinton, 2005). Komunikasi antarpribadi antara orang tua dan anak harus berlangsung dengan baik, dimana orang tua dapat berperan sebagai pembuat peraturan bagi anak-anaknya, tapi disisi lain memberikan ruang diskusi untuk anak-anaknya. Jika komunikasi antarpribadi antara orang tua dan anak telah berlangsung dengan baik, maka kepercayaan diri anak pun dapat berkembang dengan lebih baik. Selain itu, orang tua disini juga terus memberikan dukungan untuk anaknya. Mereka mencari apa yang menjadi bakat dan minat dari anak-anaknya, kemudian dengan sebisa mungkin mendukung anak-anaknya untuk mengembangkan setiap bakat dan potensi mereka.

\section{Simpulan}

Berdasarkan penelitian yang telah dilakukan, peneliti menarik beberapa kesimpulan sebagai berikut:

1. Semua orang tua dan anak setuju bahwa komunikasi merupakan hal yang penting dalam suatu hubungan. Namun, kesadaran ini tidak cukup membuat orang tua dan anak memiliki komunikasi yang baik.

2. Orang tua yang dapat menggunakan gaya komunikasi lingkaran dan roda pada saat yang tepat dan seimbang, dapat membuat anak lebih terbuka dan sering bercerita. Orang tua tak hanya berperan sebagai pembuat peraturan, namun juga berperan sebagai teman diskusi bagi anak-anaknya.

3. Anak yang terbuka dengan orang tuanya memiliki kepercayaan diri yang lebih baik dari pada anak yang tertutup dengan orang tua.

4. Anak usia remaja ternyata masih belum memiliki self-esteem atau cara pandang yang positif mengenai dirinya. Kepercayaan diri yang baik dalam diri anak, tidak menjamin anak tersebut sudah memiliki cara pandang yang baik dan positif mengenai dirinya.

\section{Ucapan Terima Kasih}

Puji dan syukur kepada Tuhan Yang Maha Esa karena atas segala berkat dan rahmat-Nya peneliti dapat menyelesaikan laporan penelitian ini dengan baik. Dalam penulisan skripsi ini, peneliti juga mendapatkan dukungan dari banyak pihak. Sehingga, peneliti ingin berterimakasih kepada pihak-pihak yang telah membantu dan memberi dukungan kepada peneliti, yakni : dosen pembimbing, keluarga, dan temanteman. 


\section{Daftar Pustaka}

Budyatna, Muhammad dan Leila Mona Ganiem. (2012). Komunikasi Antarpribadi. Jakarta: Kencana.

DeVito, Joseph. A. (2016). The Interpersonal Communication Book (14th Ed.). England: Pearson Education.

Gunarsa, Singgih D. (2008). Psikologi Perkembangan Anak dan Remaja. Jakarta: BPK Gunung Mulia.

Gunawan, Imam. (2014). Metode Penelitian Kualitatif: Teori dan Praktik. Jakarta: Bumi Aksara

Harapan, Edi dan Syarwani Ahmad. (2016). Komunikasi Antarpribadi: Perilaku Insani Dalam Organisasi Pendidikan (ed.1, cet.2). Jakarta: PT RajaGrafindo Persada.

Kholifah, Siti dan I Wayan Suyadnya. (2018). Metodologi Penelitian Kualitatif: Berbagi Pengalaman dari Lapangan. Depok: Rajawali Pers.

Liliweri, Alo. (2017). Komunikasi Antar Personal. Jakarta: Prenada Media.

Mulyana, Deddy. (2005). Ilmu Komunikasi Suatu Pengantar. Bandung: PT Remaja Rosdakarya.

Setiawan, Catherine dan Suzy Azeharie. (2017). Studi Komunikasi Antarpribadi Anak dengan Orang Tua Tiri. Laporan Penelitian Fakultas Ilmu Komunikasi Universitas Tarumanagara. Juli, 1, 2017. Terarsip di: https://journal.untar.ac.id/index.php/komunikasi/article/view/79/646 